\title{
Bearing Capacity of Soft Marine Soil Stabilization with Cockel Shell Powder (CSP)
}

\author{
Masyitah Md Nujid, Juliana Idrus, Duratul Ain Tholibon, Nor Faizah Bawadi, Ali Akbar Firoozi
}

\begin{abstract}
The quality of the subgrade is depending on the geotechnical properties, strength and the stabilization technique adopted for problematic soil in order to increase the bearing value. In Malaysia, soft soil is a challenging due to very low strength value and low California Bearing Ratio (CBR) value as well. The soil stabilization process is conducted to increase bearing capacity of marine soil. An experimental works cover from identification of basic soil properties by index test, compaction test and CBR test. Though, the marine soils have to be treated and stabilized with available methods like using natural materials or additive agents. In this study, geotechnical characteristics of marine soil stabilized with CSP content were determined. The unsoaked treated marine soil stabilized with CSP was investigated. Four different compounds of the soil with 2.5, 5, 7.5 and $10 \%$ of CSP were mixed and added to determine the unsoaked CBR of the stabilized soil compounds. The results show the inclusion of CSP reduced the plasticity of the soil and highest dry density was decreased with an increase in the optimum water content. Moreover, by increasing the content of CSP the highest CBR value at 2.5 and $5.0 \mathrm{~mm}$ penetrations were achieved. The increasing percentage volume of water usage indicates the decreasing value of $C B R$. The results indicated that CSP contents have potential as a natural stabilizer for applications such as road sub-base material in road construction. The road sub-base will gain great strength with addition of CSP on marine soil.
\end{abstract}

Keywords : Geotechnical properties; Bearing ratio; Marine soil; Cockle Shell Powder (CSP), California Bearing Ratio (CBR)

\section{INTRODUCTION}

Highway and transportation infrastructures i.e. roads, embankments, bridges, and railroads in developed and developing countries function as a form of medium to connect people, goods, and services from place to place. It is

Revised Manuscript Received on February 05, 2020.

* Correspondence Author

Masyitah Md Nujid*, Faculty, Department of Civil Engineering, University of Technology MARA, 13500 Permatang Pauh, Pulau Pinang, Malaysia. Email: masyitahmn@uitm.edu.my

Juliana Idrus, Faculty, Department of Civil Engineering, University of Technology MARA, 13500 Permatang Pauh, Pulau Pinang, Malaysia. Email: julianaidrus@uitm.edu.my

Duratul Ain Tholibon, Faculty, Department of Civil Engineering, Universiti Teknologi MARA, Campus Jengka, 26400 Bandar Tun Razak, Pahang, Malaysia. Email: duratulain@uitm.edu.my

Nor Faizah Bawadi, School of Environmental Engineering, Universiti Malaysia Perlis, Kompleks Pusat Pengajian Jejawi 3, 02600 Arau, Perlis, Malaysia. Email: norfaizah@unimap.edu.my

Ali Akbar Firoozi, Department of Civil \& Structural Engineering, Universiti Kebangsaan Malaysia (UKM), Bangi, Selangor, Malaysia. Email: a.firoozi@gmail.com

(C) The Authors. Published by Blue Eyes Intelligence Engineering and Sciences Publication (BEIESP). This is an open access article under the CC BY-NC-ND license (http://creativecommons.org/licenses/by-nc-nd/4.0/) also a symbol of country development in providing good facilities to cities and communities. Geotechnical components such as fill material are used as an important material in the construction of road pavements which can influence the sustainability of infrastructures function to bear and carry traffic loading from road surface to subgrade layer. Due to the high demand for infrastructures projects with limited land available, marine soil is used as subgrade in road construction. However, the marine soil has low soil strength for a problematic soil which is not suitable for road embankments on highways. The geological deposit of tropical weak marine soils is found in coastal and in a few offshore areas of Peninsular Malaysia (e.g. Perlis, Kedah, Pulau Pinang, Malacca, and Selangor). Initial conditions of marine soil will determine its physical and chemical composition properties [2,31]. It has a higher percentage of silica and aluminum and contains decayed organic matters such as sea shell which has potential as cementing agents.

Soils contain organic matters are dark gray to black in color and an odor of decomposition which agree to marine soils color [16]. The composition of decayed organic matters which react with marine soil can give effect on its structure hence engineering properties. The slaking sensitivity of fine grain soils can be seen from the organic material percentage substance present in the soil and prone to sandy silty soils and low of clay content [8]. Presence of high water content in soil containing organic matter may behave as a reversible swelling and vice versa. The Atterberg limit of 10-20\% clay content may increase liquid limit consistency with increase the organic carbon content.

From engineering properties, compacted densities and compressive strength decrease significantly with increased organic content. The increase in organic content will increase the optimum water content for compaction [16]. The presence of water when reacts with organic matter in marine soils can have an effect on water holding capacity and cation exchange capacity [10]. The water holding capacity is reliant on the grain and soil type, energy apply and soil surface. The cation exchange capacity is reliant on the grain and $\mathrm{pH}$ range of the soil which controlling amount of swelling fine soils (i.e expansive clay minerals) [18].

In previous years many research studies on soil stabilization techniques to improve soil properties have been done. Among them were studies using chemical additives such as natural cement and lime [33,29,2,12,12,26,6,35]. The existence of lime in soil stabilization cause to the absence of sulfates which bring the decrease in the repulsion forces among the clay grains makes a bond between them and shapes flocks.

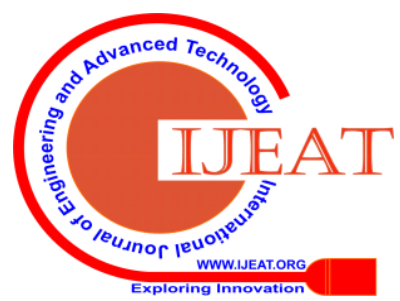


The lime also reduces the result of consistency limit of plasticity index and the highest dry density of treated soil but increase their optimum moisture content. In addition, by using lime as cement binder in soil stabilization can cause $\mathrm{CO}_{2}$ emission when it reacts with water. When lime responds with water in the soil from the hydration process, hydrated lime is formed [26,19] and release $\mathrm{CO}_{2}$ as a by-product. A reaction with $\left(\mathrm{Ca}(\mathrm{OH})_{2}\right)$ and the presence of $\mathrm{CO}_{2}$ in atmospheric will release the final product of calcium carbonate $\left(\mathrm{CaCO}_{3}\right)$ and water precipitation which is called carbonation process. It is a process where the presence of $\mathrm{CO}_{2}$ results in $\mathrm{CaCO}_{3}$ crystal acts as a binder due to the interconnected microstructure joining with the rest of element in the mix [19]. Thus, lime can be categorized into three types base on chemical composition and the chemical process involved in the formation of it. The product of sedimentary rocks and minerals by various chemical lime, and hydrated lime slurry from its formation of limestone [10].

The high demand for both materials (cement and lime) and the cost of energy have increased the price of the materials. pollute the environment and nature. Hence, natural waste is proposed to replace the method. The natural stabilization can be used to reduce the usage of chemical stabilization in soil kernel shell [5], coconut shell [9], rice ash rusk [11], seashell product from different industries like as agricultural waste [1] and others (e.g. municipal solid waste incinerator ash [28].

This study is focused on the natural seashell wastes in stabilizing properties of weak marine soils by adopting cockle shell waste powder in the soil mixture. The seashell waste is an abundant material such as oyster shells, cockle shells, and mussel shell. By recycling waste products which are mostly found in landfill or open dumping areas, the huge amount is available as an alternative eco-friendly product for marine stabilized soils. The introduction of seashell waste as potential in replacing cement by-product is due to the main chemical composition of seashell ( $90 \%$ of calcium carbonate) is similar to the Portland cement production, primary consisting of calcium oxide with a tiny fraction of other oxides [13]. The seashell ash shows a great potential of using natural stabilizer in soil stabilization technique. The experimental evidence show seashell as cement replacement can increase tensile and compressive strengths at certain percentage replacement of seashell $[20,32,15]$. This is also true from previous findings show the cockle shell powder has potential as partial cement replacement in concrete $[19,20,21]$. Thus, the chemical compounds in cockle shell exhibit similar chemical production when it reacts with water and soil compositions.

Comparisons on the chemical composition in Table 1 shows of seashell [22] and cockle shell [20,15] with calcium oxide as the highest component in the composition. Previous studies include crushed seashell [25], cockle shell [15], oyster shell [4,34], eggshell [27] and periwinkle shell [23]. Most applications of seashell wastes in the construction limestone from chemical weathering (decomposition of processes) at elevated temperatures is quicklime, hydrated The chemical improvement is a time-saving method as it enables the subgrade layer to increase its strength but can improvement. The natural additives, for instance, are palm wastes [22] and [13]. Some natural additives are a waste

industry are quarry dust and aggregate, and subgrade stabilization for pavement purpose.

Table-1: Chemical compositions of seashell and cockle shell $[22,15,20]$

\begin{tabular}{|c|c|c|c|}
\hline \multirow{2}{*}{ Oxide } & \multicolumn{3}{|c|}{ Percentage (\%) } \\
\cline { 2 - 4 } & $\begin{array}{l}\text { Ground } \\
\text { seashell } \\
\text { [22] }\end{array}$ & $\begin{array}{l}\text { Cockle shell } \\
\text { ash } \\
\text { [15] }\end{array}$ & $\begin{array}{l}\text { Cockle shell } \\
\text { ash } \\
\text { [20] }\end{array}$ \\
\hline $\mathrm{SiO}_{2}$ & 1.60 & - & 0.07 \\
\hline $\mathrm{Al}_{2} \mathrm{O}_{3}$ & 0.92 & - & 0.03 \\
\hline $\mathrm{CaO}$ & 51.56 & 98.99 & 99.00 \\
\hline $\mathrm{MgO}$ & 1.43 & - & - \\
\hline $\mathrm{Na}_{2} \mathrm{O}$ & 0.08 & - & 0.49 \\
\hline $\mathrm{K}_{2} \mathrm{O}$ & 0.06 & - & 0.06 \\
\hline $\mathrm{H}_{2} \mathrm{O}$ & 0.31 & - & - \\
\hline $\mathrm{P}_{2} \mathrm{O}_{5}$ & - & - & 0.03 \\
\hline $\mathrm{SO}_{3}$ & - & - & 0.14 \\
\hline $\mathrm{Fe} \mathrm{O}_{3}$ & - & - & 0.05 \\
\hline $\mathrm{Mg}$ & - & 0.51 & - \\
\hline $\mathrm{Si}$ & - & 0.078 & - \\
\hline $\mathrm{Na}$ & - & - & - \\
\hline $\mathrm{LOI}$ & 41.48 & - & 0.20 \\
\hline $\mathrm{Others}$ & - & $<0.1$ & 0.28 \\
\hline
\end{tabular}

Cockle shell waste became an alternative in stabilization method of marine soil which includes calcium carbonate and calcium oxide. It has a chemical composition similar to cement additives [15] and lime binder [26]. The chemical structure of cockle shell was analyzed using $x$-ray fluorescence $[15,20]$. From the table 1, the cockle shell ash containing 99\% $\mathrm{CaO}$ and rich in calcium (Ca) element with its loss in the ignition (LOI) of its content is $0.2 \%$ [20]. The $\mathrm{XRF}$ result indicates the presence of lime, $\mathrm{CaO}$ and calcium carbonate, $\mathrm{CaCO}_{3}$ in the calcite cockle shell. The presence of the calcite cockle shell due to the calcination process of the cockle shell converts $\mathrm{CaCO} 3$ contained into $\mathrm{CaO}$ at high temperature. Furthermore, equation (1) represents the decomposition process of cockle shell which is denoted by decomposition of $\mathrm{CaCO}_{3}$ known calcination at high temperature.

$\mathrm{CaCO}_{3}(\mathrm{~s}) \leftrightarrow \mathrm{CaO}(\mathrm{s})+\mathrm{CO}_{2}(\mathrm{~g})$

M. Mohamed [15] and Nor Hazurina [20] showed the burning of cockle shell ash comprising calcium carbonate $\left(\mathrm{CaCO}_{3}\right)$ through thermal decomposition process with calcium carbonate can be transferred into calcium oxide $(\mathrm{CaO})$ as shown in Eq. (1). The $\mathrm{CaCO}_{3}$ contained into $\mathrm{CaO}$ after convertion the thermal decomposition of cockle shell.

The fundamental mechanisms involved in the treatment using cockle shell can be seen from the crystal structure of the soil by using $\mathrm{x}$-ray diffraction (XRD) and scanning electron microscopy (SEM) to count the changes in the physical properties and compositions of the cockle shell ash. The crystal structure using XRD and physical properties show that raw cockle shell is produced up of aragonite, $\mathrm{CaCO}_{3}[15,20]$. 
The aragonite which has higher density and hardness is a crystal form of calcium carbonate other than calcite and vaterite and it is suitable to be used in any field industry such as in concrete mix design $[15,20]$.

In Malaysia, cockle shell waste can be found in the state west coast of Peninsular Malaysia [20,21]. Moreover, the cockle shell inserted in the subgrade layer is to improve not only the strength but also the durability of soil. By using cockle shell as materials in stabilization technique it will reduce the environmental impact of the stabilization activity.

The research is conducted to look at the geotechnical properties and bearing ratio of marine soil with the influence of cockle shell powder as a natural additive for pavement layer in road construction. The significant of the use of cockle shell powder as natural stabilizer it is can minimize the use of chemical additives such as lime/cement which may affect to environmental pollution by producing carbon dioxide $\left(\mathrm{CO}_{2}\right)$ emission. Also, cockle shell which has a similar composition as cement additive is easy to be found and collected at the abundant source were close to the nearby coastal area in Malaysia. The soil strength of road subgrade for infrastructure constructions become stronger and stable.

\section{SOIL MATERIALS AND METHODOLOGY}

The soft soil samples were gathered and performed from the seaside area of Kuala Muda, Kedah, Malaysia (Fig. 1) [37]. Soft soil samples were collected by hand tool at the jetty beach zone. The physical properties of marine soil were indicated by the soil color which was grey as a result of oxidation of sulfur and iron in the clay (chemical weathering) [24] and contained organic matters. The natural water content of marine soil was preserved in a container and samples of disturbed samples were collected and transported to a geotechnical laboratory for testing. The impurities such as debris were removed from collected samples before heating in an oven at $100^{\circ} \mathrm{C}-110^{\circ} \mathrm{C}$ temperature for a week. The marine soils condition after seven days was oven-dried was shown in Fig. 2.

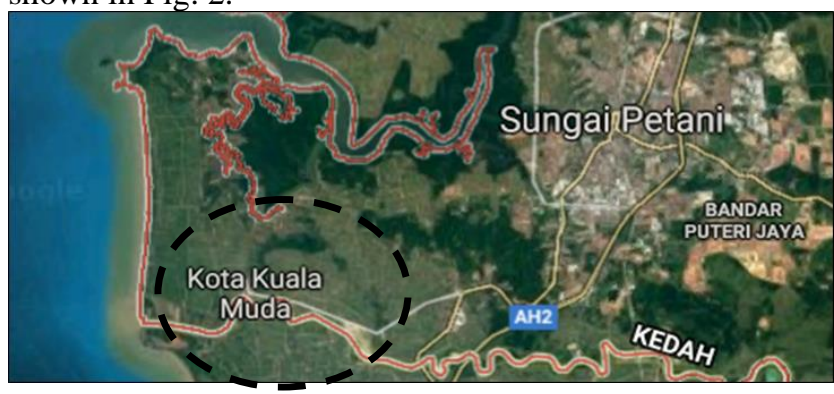

Fig. 1. The sampling point for the soft soil in Kedah

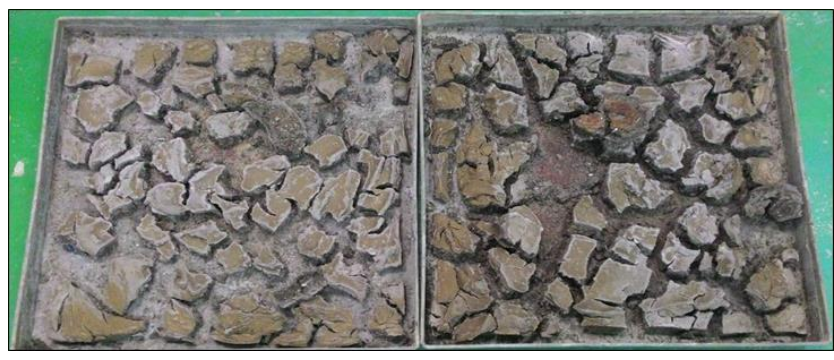

Fig. 2. The soil condition after seven days of oven-dried

\section{A. Material Preparation}

The shells were washed and dried in an oven for 24 hours at the temperature $25-30^{\circ} \mathrm{C}$. The powders from cockle shells were formed using an abrasion machine (ASTM C131) were sieved by passing through a $0.063 \mathrm{~mm}$ sieve was used for the testing. Finally, the cockle-shell powders (CSP) were mixed with dried marine soils at a different percentage of 2.5, 5.0, 7.5, and $10.0 \%$ by dry weight of soil. Approximately $3 \mathrm{~kg}$ of dried marine soils were used and the cockle shell powders weight varies according to the percentage given. Details on mix soils and cockle shell powders proportion are given in Table 2 .

Table-2: Mixture on soils and powders [37]

\begin{tabular}{|c|c|c|c|}
\hline No & $\begin{array}{l}\text { Percentage } \\
\text { Marine } \\
\text { soil (\%) }\end{array}$ & $\begin{array}{l}\text { Percentage } \\
\text { Cockle shell } \\
\text { powder, CSP } \\
\text { content (\%) }\end{array}$ & Remark \\
\hline 1 & 100 & 0 & Untreated \\
\hline 2 & 100 & 2.5 & Treated \\
\hline 3 & 100 & 5.0 & Treated \\
\hline 4 & 100 & 7.5 & Treated \\
\hline 5 & 100 & 10.0 & Treated \\
\hline
\end{tabular}

\section{B. Material Testing}

The resistance to crushing and abrasive wear of aggregate was assessed by means of a Los Angeles abrasion machine, according to ASTM C131. Samples of $10.0 \mathrm{~mm}$ and $14.0 \mathrm{~mm}$ aggregates were weighed and oven-dried. The sample used was $2.5 \mathrm{~kg}$ for each size. The samples were placed in the drum along with 11 steel balls. The drum was rotated for 15 minutes. Then, the sample was separated using a $1.7 \mathrm{~mm}$ sieve. This process was done manually. Then, the material that passes the $1.7 \mathrm{~mm}$ sieve was considered a loss and dismissed (or rejected). The consistency of Atterberg's limit test in accordance to BS 1377: Part 2:1990. The determination of the specific gravity of the marine clay samples was established by using the pyknometer bottle technique. Dry-sieving to determine the particle size distribution and if the percentage soils at the last pan were greater than $10 \%$, the experiment will then continue with the hydrometer test. Cone penetration test was conducted to determine the liquid limit at $20 \mathrm{~mm}$ penetration. The soil thread into a $3 \mathrm{~mm}$ diameter without crumbling was formed to determine plastic limit. The Plasticity Chart is used to determine consistency or plasticity of soil. Furthermore, $3 \mathrm{~kg}$ of soil sample passing $37.5 \mathrm{~mm}$ sieve was prepared for compaction testing and $7 \%$ of water by soil weight were added to the soil sample. Compaction characteristic tests were performed using $2.5 \mathrm{~kg}$ standard Proctor (also known BS Light). In three layers of compacted soil by using a rammer where each layer experienced 27 blows that were evenly distributed over the mould area. The maximum dry density, $\rho d_{\max }$, and optimum moisture content, wopt can be achieved from the compaction curve. The laboratory work was conducted based on BS 1377: Part 4: 1990. This method was carried out to determine the compaction characteristic of soil sample. Finally, the objective of the California Bearing Ratio (CBR) test in accordance to BS 1377: Part 4: 1990 to determine bearing of subgrade soil. The CBR tested for the soil only and combination between soil and cockle shell as stated in Table 2. 
For sample preparation in conducting the experiment, first of all, the soil was sieved through a size of $20 \mathrm{~mm}$ sieve until a mass of about $6 \mathrm{~kg}$ was produced. The soil and water were mixed together on the tray. Then, the soil was divided into five portions. The mould and base plate were cleaned using a brush and the initial mass was recorded. The matured soil sample was remixed and compacted in the mould in five layers using the rammer at 62 blows per layers. The collar was removing and the excess soil was cut with the straight edge to get accurate data. The mould and base were weighted and the mass recorded. Next, the mould and base plate was placed at the CBR machine, and the machine was switched on and penetration process took place on top and bottom of the soil sample then the load ring dial reading was recorded. The soil sample was taken out from the mould, where the soil specimen at the top, middle and bottom were determined for water content.

\section{RESULT AND DISCUSSION}

The index characteristics of the marine soil from Kedah are shown in Table 3. The value of Gs is 2.27 which is lower from range results produced by $[2,24,30]$. Classification of marine soil is SILT of high plasticity $(\mathrm{MH})$. From Table 3, it shows that the silt fraction is $50.37 \%$ dominated in soil samples, a sand fraction is $41.05 \%$. The marine soil samples show the clay fraction is $8.44 \%$. The marine soil samples have shell fragments and muddy seaside area of Peninsular Malaysia presence of higher silt and clay [2,24]. However, the present results indicate the clay fraction was a small percentage compared to silt and sand. The hand auger technique in sampling process samples collected close to the sandy beach area which led to sand particles.

Table-3: Marine soil index properties used in this study [37]

\begin{tabular}{|c|c|}
\hline Soil properties & Values \\
\hline Original moisture content (\%) & $88-125.17$ \\
\hline Specific gravity (Gs) & 2.27 \\
\hline Sand (\%) & 41.05 \\
\hline Silt (\%) & 50.37 \\
\hline Clay (\%) & 8.44 \\
\hline Liquid limit, LL (\%) & 68 \\
\hline Plastic limit, PL (\%) & 32 \\
\hline Plasticity index, PI (\%) & 36 \\
\hline Maximum dry density, $\rho d_{\max }$ & 1.64 \\
\hline Optimum moisture content (\%) & 16.34 \\
\hline
\end{tabular}

The Atterberg limits from the soil samples typically reflect marine clay from Asia countries mostly [2,24,14,30].

\section{A. Effect of CSP on specific gravity}

Specific gravity (Gs) of the soil could be determined by conducting particle density test. Specific gravity is described as the ratio between the unit masses of soil particles and water. The average of specific gravity for original soil is 2.27 which means it is below 2.6 and this is due to soil has contained organic matter and porous particles.

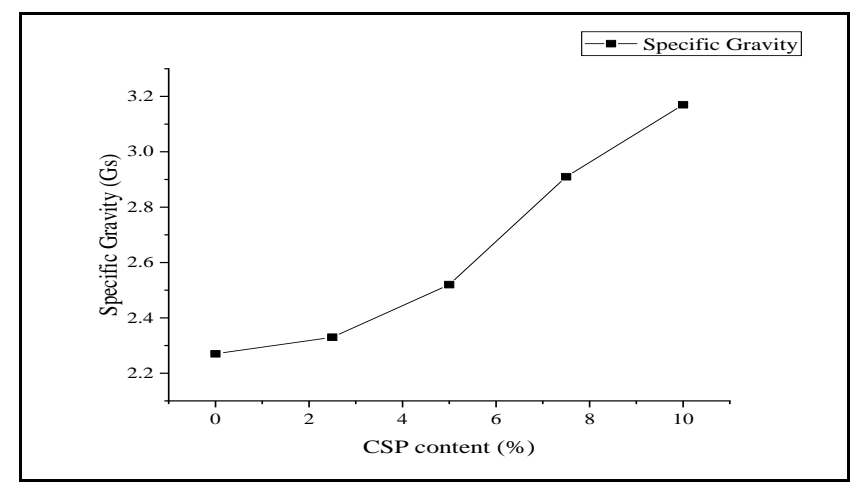

Fig.3. The specific gravity (Gs) and the percent of CSP content $(0,2.5,5,7.5$, and $10 \%)$

For $2.5,5,7.5$, and $10 \%$ of CSP added, the specific gravity was reported 2.33, 2.5, 2.91, and 3.17. Also, Fig. 3 shows the Gs rise gradually as the number of stabilizer increases. The Gs for untreated soil in present study is found low because the organic matter was found in the soil composition. A study conducted by [25], the addition of crushed seashell stabilizer on sandy soil stabilization made the Gs from original soil decrease.

\section{B. Effect of CSP on Atterberg limit}

The liquid limit, LL and plastic limit, PL for untreated and treated marine soil are shown in Table 4 and Fig. 4. The treated marine soil liquid limit, LL values ranged between from 15 to $21 \%$ while the treated marine soil plastic limit, PL values were between 37 and $44 \%$ for different percentage of CSP content.

Table-4: Summary of the Atterberg limits for different percentage of CSP content [37]

\begin{tabular}{|c|c|c|c|}
\hline $\begin{array}{c}\text { CSP } \\
\text { content } \\
\mathbf{( \% )}\end{array}$ & $\begin{array}{c}\text { Percentage } \\
\text { liquid limit, } \\
\text { LL (\%) }\end{array}$ & $\begin{array}{c}\text { Percentage } \\
\text { plastic limit, } \\
\text { PL (\%) }\end{array}$ & $\begin{array}{c}\text { Percentage } \\
\text { plasticity } \\
\text { index, PI } \\
\text { (\%) }\end{array}$ \\
\hline 0 & 36 & 68 & 32 \\
\hline 2.5 & 27 & 17 & 44 \\
\hline 5.0 & 24 & 21 & 45 \\
\hline 7.5 & 22 & 15 & 37 \\
\hline 10.0 & 19 & 18 & 37 \\
\hline
\end{tabular}

For treated marine soil samples the plasticity index in a range between 19 to $27 \%$. Hence, the soil samples can be classified as low plasticity index which referring from plasticity chart, all samples lie below the A-line representing silt with low plasticity. The Atterberg's limit of marine soil is primarily controlled by its clay content such as montmorillonite and kaolin [36], especially on the liquid limit. The montmorillonite clay minerals are known has the ability to increases the water holding capacity of soil due to the high specific surface area thus increasing the liquid limit of soils. The plasticity of soil reduced due to addition of CSP decreases the water holding [35]. Moreover, the combination of non-flaky of silt particles and very flaky of clay particles which changes in water content resulted in reducing plasticity index. 
There is not XRD/SEM experimental and analysis conducted in the present study to observe the mineral composition and microstructure of the marine soil.

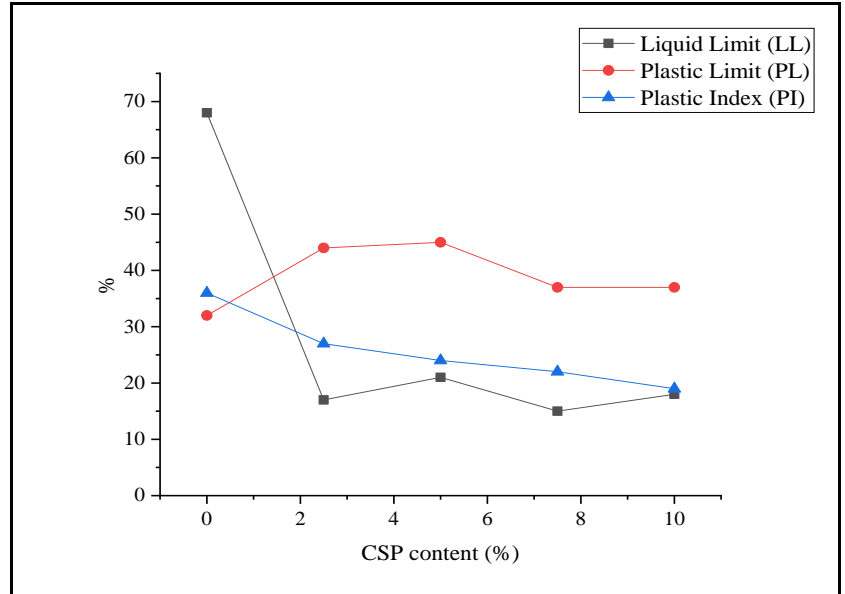

Fig. 4. Atterberg limits consistency and the percentage of CSP content $(0,2.5,5,7.5$, and $10 \%)$

\section{Effect of CSP on Compaction Characteristics}

The compaction results of marine soil stabilized with CSP is shown in Fig. 5 and Table 5. The results show that there is a decreasing trend in the Maximum Dry Density (MDD) value and increasing trend in the Optimum Moisture Content (OMC) value with increase in CSP percentage content. This behavior may be attributed to the reduction of average unit weight of solids in the mixture of soil and powder. When chemical compounds of CSP reacts with water in the hydration process, heat is released. The heat generated could evaporate additional moisture from water present in the soil participates cause to dried soils[10]. From the chemical reaction changes in the soil which reduce its capacity to hold water and increase stability. Thus, the soil is become easier to compact and work since flocculation and agglomeration have taken place in the soil mixture with CSP. It also makes the calcium ions from the $\mathrm{CaCO}_{3}$ transfer to the surface of the clay particles and replace water and other ions [10]. This also brings a similar effect with the presence of organic matter in soil composition characterized by high water with holding capacity that may lead to a decrease in available water for the hydration process. The increase in organic content causes an increase in the optimum water content for compaction [16].

Table-5: Summary of the MDD and OMC values for different percentage of CSP content

\begin{tabular}{|c|c|c|}
\hline $\begin{array}{c}\text { Percentage of } \\
\text { CSP in soil } \\
\text { sample (\%) }\end{array}$ & $\begin{array}{c}\text { Maximum dry } \\
\text { density (Mg/m }\end{array}$ & $\begin{array}{c}\text { Optimum } \\
\text { moisture } \\
\text { content (\%) }\end{array}$ \\
\hline 0 & 1.64 & 16.34 \\
\hline 2.5 & 1.39 & 18.72 \\
\hline 5.0 & 1.37 & 25.37 \\
\hline 7.5 & 1.35 & 26.91 \\
\hline 10.0 & 0.90 & 31.18 \\
\hline
\end{tabular}

The observations are in agreement with [36] which the reduction of MDD value due to the reduction in the proportion of silt particles which retains a higher density. The high-water-content separates the high-density silt particles from each other and as a result, the maximum dry density decreases. By adding CSP content increases the OMC and MDD decrease. The increase of OMC and decrease in MDD results from the present study showed similar results studied by [27] with the addition of eggshell powder in clayey soil and of clayey soils stabilized with lime additive [12].

In contrast to the present finding, by using cement-dust-shell (DS) in soft soil stabilization, the addition of additives slightly increases the maximum dry density and reducing optimum moisture content $[29,17]$. The increase in the dry density occurs because the agglomerated and flocculated particles of soil occupy larger spaces and the reason for reducing OMC is that, the cement requires more water for the pozzolanic reactions. Similar results could be seen when crushed seashell was added to sandy soil for stabilization purpose [25]. The soil-additive mixture is acting as a binder between particles as a soil matrix and crushed seashell as a dispersed phase with less of surface contact (shape and size particles) generates more voids thus reduce soil density.

\section{Effect of CSP on California Bearing Ratio (CBR) Characteristics}

The CBR results of marine clay soil stabilized with varying percentage of CSP content under unsoaked condition are presented in Fig.6a and $6 \mathrm{~b}$ respectively. The results show the bearing ratio of measured force to standard force at 2.5 $\mathrm{mm}$ and $5.0 \mathrm{~mm}$ penetration for top and bottom faces of soil. The CBR value of soil samples increased gradually as the percentage of CSP increases with constant of $2.5 \%$ increment. 


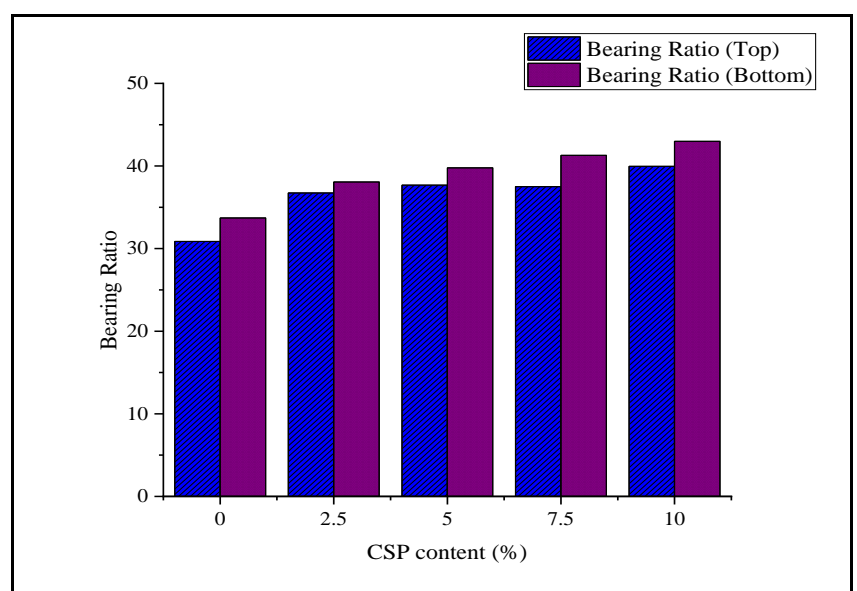

Fig.6a. Bearing ratio of stabilized marine clay with varying CSP content $(0,2.5,5,7.5$, and $10 \%)$ at $2.5 \mathrm{~mm}$ penetration

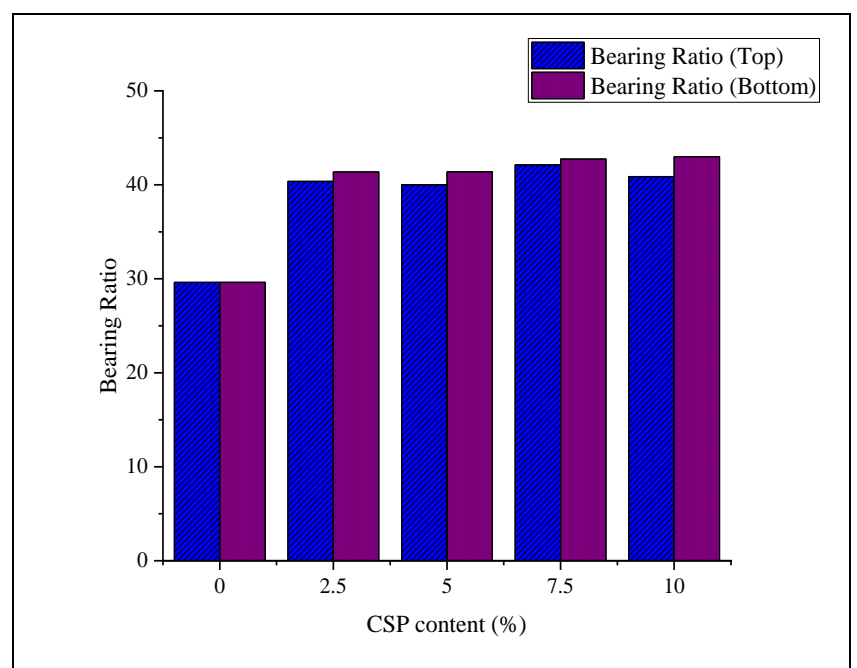

Fig.6b. Bearing ratio of stabilized marine clay with varying CSP content $(0,2.5,5,7.5$, and $10 \%)$ at $5.0 \mathrm{~mm}$ penetration

For comparison purpose, Fig. 7a and $7 \mathrm{~b}$ indicates the bearing ratio values at $2.5 \mathrm{~mm}$ penetration are higher than the bearing ratio value at $5.0 \mathrm{~mm}$ penetration for $0 \%$ of CSP content. As CSP content increase, the bearing ratio value exhibits increment value for top and bottom parts at $2.5 \mathrm{~mm}$ and $5.0 \mathrm{~mm}$ penetration respectively.

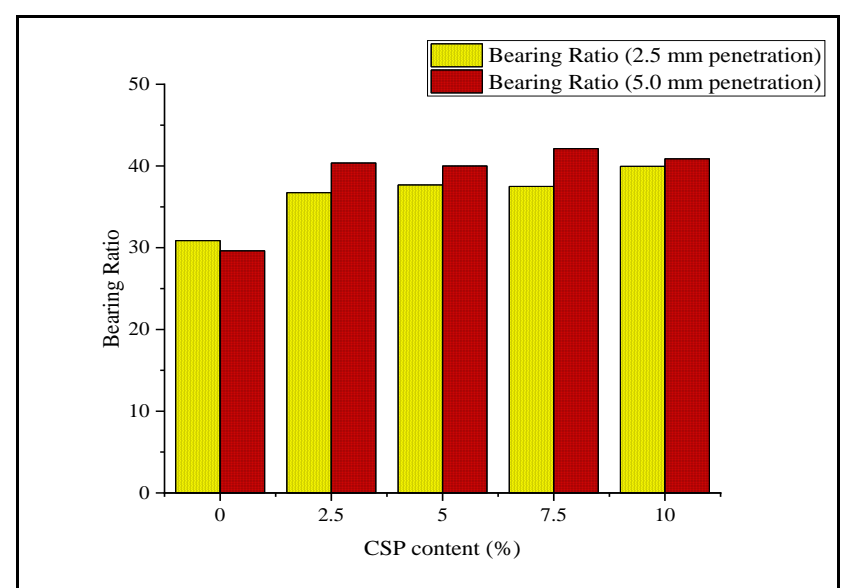

Fig.7a. Comparison of bearing ratio with the percentage of CSP content at $2.5 \mathrm{~mm}$ and $5.0 \mathrm{~mm}$ penetration (top part)

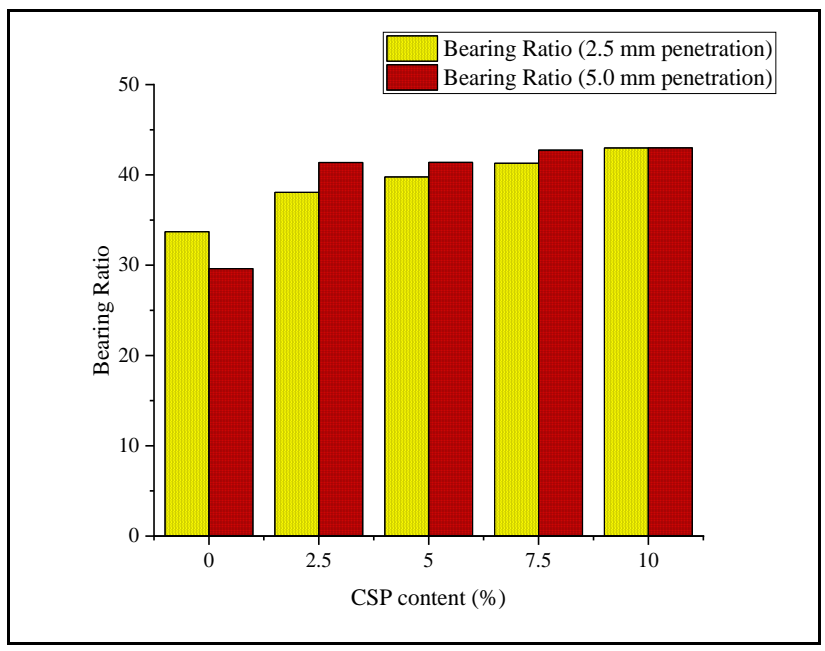

Fig.7b.Comparison of bearing ratio with the percentage of CSP content at $2.5 \mathrm{~mm}$ and $5.0 \mathrm{~mm}$ penetration

(bottom part)

The CBR value increase is due to the soil particles are surrounded by CSP with the presence of calcium carbonate and calcium oxide show similar chemical composition to cement additives. The CSP is acting as a binder between the additive and soil particles which give reactions for the increase in the CBR. Thus, the soil particles can resist a higher force by penetration acting on it and therefore the CBR value increase. Similar trends were also shown from studies conducted by $[1,11,12]$ on the effects of adding lime, rice husk ash (RHA), pond ash (PA) and ordinary Portland cement on the clayey soils.

\section{CONCLUSION}

In the present study, the geotechnical properties and the bearing ratio of marine clay soil with the influence of cockle shell powder as a natural stabilizer for pavement layer in road construction were investigated. The marine clay soil was stabilized with CSP content ranging from 0, 2.5, 5, 7.5, and $10 \%$. The index testing, compaction test, and California Bearing Ratio test were conducted to determine the marine clay soil stabilized with CSP. Generally by adding CSP to marine soil will decrease LL, PI and MDD of the soil, and increases its OMC. Based on the results, the following conclusions may be drawn:

(1) The LL and PL decrease with an increase in the CSP content. Thus the plasticity index of stabilized marine clay soil with CSP decreases. This is due to the reduction in the water holding capacity resulting in an insignificant reduction of the plasticity of the marine clay.

(2) The OMC and the MDD are influenced by CSP inclusion, whereas the optimum water content increases and the maximum dry density reduces. This can be attributed to the reduction of average unit weight of solids in the soil-powder mixture.

(3) The unsoaked California bearing ratio increases with an increase in the CSP content. The bearing ratio results show that the presence of CSP helps to improve the CBR value.

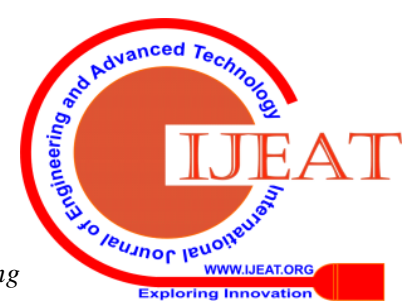


This improvement is due to an interaction between soils with CSP content which contain calcium carbonate and calcium oxide show similar to chemical composition to cement additives.

\section{ACKNOWLEDGEMENT}

The authors are thankful to University of Technology MARA, Pulau Pinang for allowing research been conducted and performed in Geotechnical Laboratory. The authors appreciate the undergraduate students for their cooperation in this research.

\section{REFERENCES}

1. Ali, M., Saberian, M., \& Li, J. Soil stabilization with non-conventional eco-friendly agricultural waste materials: An experimental study. Transportation Geotechnics, 2018;14:52-60. https://doi.org/10.1016/j.trgeo.2017.09.004

2. Anggraini, V., Asadi, A., Syamsir, A., \& Huat, B. B. K. Three point bending flexural strength of cement treated tropical marine soil reinforced by lime treated natural fiber. Measurement, 2017;111(July):158-166. https://doi.org/10.1016/j.measurement.2017.07.045

3. ASTM C131/C131M. Standard test method for resistance to degradation of small-size coarse aggregate by abrasion and .impact in the Los Angeles Machine. ASTM International, West Conshohocken, PA, USA: ASTM International 2006.

4. Augusto, R., Alvarenga, F. De, Galindro, B. M., Helpa, C. D. F., \& Soares, S. R. The recycling of oyster shells : An environmental analysis using Life Cycle Assessment. Journal of Environmental Management, 2012;106:102-109. https://doi.org/10.1016/j.jenvman.2012.04.017

5. Awalludin, M. F., Sulaiman, O., Hashim, R., \& Aidawati, W. N. An overview of the oil palm industry in Malaysia and its waste utilization through thermochemical conversion, specifically via liquefaction. Renewable and Sustainable Energy Reviews, 2015;50:1469-1484. https://doi.org/10.1016/j.rser.2015.05.085

6. Baldovino, J. A., Moreira, E. B., Teixeira, W., Izzo, R. L. S., \& Rose, J. L. Effects of lime addition on geotechnical properties of sedimentary soil. In. Journal of Rock Mechanics and Geotechnical Engineering, https://doi.org/10.1016/j.jrmge.2017.10.001

2018;10(1):188-194

7. British Standards Institution, British Standard Methods of Test for Soils for Civil Engineering Purposes, Part 2, Classification Tests, London, 1990.

8. Boekel, P. The effect of organic matter on the structure of clay soils. Neth. J. Agric. Sci., 11(4), 1963; 250-263.

9. Danso, H. Properties of Coconut, Oil Palm and Bagasse Fibres : As Potential Building Materials. In Procedia Engineering, 2017; Vol. 200: pp. 1-9. Elsevier B.V. https://doi.org/10.1016/j.proeng.2017.07.002

10. Firoozi, A. A., Guney Olgun, C., Firoozi, A. A., \& Baghini, M. S. Fundamentals of soil stabilization. International Journal of Geo-Engineering, 2017; 8(1), https://doi.org/10.1186/s40703-017-0064-9

11. Gupta, D., \& Kumar, A. Performance evaluation of cement-stabilized pond ash-rice husk ash- clay mixture as a highway construction material. Journal of Rock Mechanics and Geotechnical Engineering, 2017;9(1):159-169. https://doi.org/10.1016/j.jrmge.2016.05.010

12. Hammoud, I., \& Meziab, A. Effect of adding natural pozzolana on geotechnical properties of lime-stabilized clayey soil. Journal of Rock Mechanics and Geotechnical Engineering, 2016;8(5):714-725. https://doi.org/10.1016/j.jrmge.2016.04.002

13. Hung, K., Alengaram, U. J., Zamin, M., Cheng, S., Inn, W., \& Wah, C. Recycling of seashell waste in concrete : A review. Construction and Building Materials, 2018;162:751-764. https://doi.org/10.1016/j.conbuildmat. 2017.12.009

14. Lee, F., Lee, Y., Chew, S., \& Yong, K. Strength and Modulus of Marine Clay-Cement Mixes. Journal of Geotechnical \& Geoenvironmental Engineering, 2005;131(February):178-186.

15. M. Mohamed, Yusup, S., \& Maitra, S. Decomposition study of calcium carbonate in cockle shell. In Journal of Engineering and Science Technology, 2012;7(1):1-10

16. Mitchell, J. K. \& Soga, K. Fundamentals of Soil Behaviour. $3^{\text {rd }}$ Edition, John Wiley \& Sons, Inc. 2005.

17. Mokhtar, M., Hamid, N. B., Aimi, S., Mohd, N., \& Sani, S. An experimental study on dust shell as an admixture in soft soil stabilization. In ARPN Journal of Engineering and Applied Sciences, 2016;11(11):7254-7257.

18. Murphy, B. Key soil functional properties affected by soil organic matter - evidence from published literature. In IOP Conf.Series: Earth and Environmental Science 2015 https://doi.org/10.1088/1755-1315/25/1/012008.

19. N.F. Nor Hisham, N. Razali, N. R. Utilization Of Cockle Shells As Partial Binder Replacement In Concrete. Journal of Engineering and Technology, 2017; 8(2).

20. Nor Hazurina, O., Hisham, B. A. B., Mashitah, M. D. and Azmi, M. M J. Cockle Shell Ash Replacement for Cement and Filler in Concrete. Malaysian Journal of Civil Engineering, 2013a;25(2):201-211.

21. Nor Hazurina, O., Bakar, A. B. U., Johari, M., \& Don, M. A. T. Potential Use of Cockle ( Anadara granosa) Shell Ash as Partia Cement Replacement in Concrete. Caspian Journal of Applied Sciences Research, 2013b.

22. Olivia, M., Arifandita, A., \& Darmayanti, L. (2015). Mechanical properties of seashell concrete. In Procedia Engineering.2015; Vol. 125: $\quad$ pp. 760-764. $\quad$ Elsevier $\quad$ B.V. https://doi.org/10.1016/j.proeng.2015.11.127

23. Otoko, G. R., \& Cynthia, E. I. Mechanical stabilization of a deltaic clayey soil using crushed waste periwinkle shells. In International Journal of Engineering and Technology Research, 2014;2(5):1-7.

24. Rahman, Z. A., Yaacob, W. Z. W., Rahim, S. A., Lihan, T., Idris, W. M. R., \& M.Sani, W. N. F. Geotechnical Characterisation of Marine Clay As Potential Liner Material. Sains Malaysia, 2013;42(8):1081-1089.

25. Ruiz, G., \& Farfan, P. Use of crushed seashell by-products for sandy subgrade stabilization for pavement purpose. In 14th LACCEI International Multi-Conference for Engineering, and Technology,2016:1-6.

26. Saberian, M., Jahandari, S., Li, J., \& Zivari, F. Engineering Effect of curing, capillary action, and groundwater level increment on geotechnical properties of lime concrete : Experimental and prediction studies. Journal of Rock Mechanics and Geotechnical Engineering, 2017;9(4):638-647. https://doi.org/10.1016/j.jrmge.2017.01.004

27. Saji, G., \& Mathew, N. Improvement of clayey soil by using egg shell powder and quarry dust, IOSR Journal of Mechanical and Civil Engineering (IOSR-JMCE),2016;46-54.

28. Singh, D., \& Kumar, A. Geo-environmental application of municipal solid waste incinerator ash stabilized with cement. Journal of Rock Mechanics and Geotechnical Engineering, 2017;9(2):370-375. https://doi.org/10.1016/j.jrmge.2016.11.008

29. Suthar, M., \& Aggarwal, P. Bearing ratio and leachate analysis of pond ash stabilized with lime and lime sludge. Journal of Rock Mechanics and Geotechnical Engineering,2018;10(4):769-777. https://doi.org/10.1016/j.jrmge.2017.12.008

30. Tanaka, H., Locat, J., Shibuya, S., Soon, T. T., \& Shiwakoti, D. R. Characterization of Singapore, Bangkok , and Ariake clays. Canadian Geotechnical Journal, 2001;400, 378-400. https://doi.org/10.1139/cgj-38-2-378

31. Tarmizi, S. M., Mustafa Al-Bakri, A. M., Kamarudin, H., Ruzaid, C. M., Rafizi, A. R., \& Liyana, J. Potential of Marine Clay as Raw Material in Geopolymer Composite Potential of Marine Clay as Raw Material in Geopolymer Composite. Applied Mechanics and Materials, 2013;330:82-85.

https://doi.org/10.4028/www.scientific.net/AMM.330.82

32. Wan Ahmad Soffian Bin Wan Mohammad, Nor Hazurina Othman, Mohd Haziman Wan Ibrahim, Masazurah A Rahim, S. S. and R. A. R. A review on seashells ash as partial cement replacement. In IOP Conf.Series: Materials Science and Engineering 2017. https://doi.org/10.1088/1757-899X/271/1/012059

33. Wang, D., Zentar, R., Abriak, N. E. Durability and Swelling of Solidified / Stabilized Dredged Marine Soils with Class-F Fly Ash, Cement, and Lime, 30(3), 2018;1-12. https://doi.org/10.1061/(ASCE)MT.1943-5533.0002187.

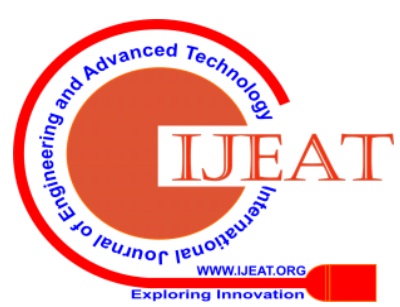


34. Yang, E., Yi, S., \& Leem, Y. Effect of oyster shell substituted for fine aggregate on concrete characteristics : Part I. Fundamental properties, 2005;35:2175-2182. https://doi.org/10.1016/j.cemconres.2005.03.016

35. Zainuddin, N., Mohd Yunus, N. Z., Al-Bared, M. A. M., Marto, A., Harahap, I. S. H., \& Rashid, A. S. A. Measuring the engineering properties of marine clay treated with disposed granite waste. Measurement: Journal of the International Measurement Confederation, $\quad$ 2019;131:50-60. https://doi.org/10.1016/j.measurement.2018.08.053

36. Zhang, K., \& Frederick, C. N. Experimental investigation on compaction and Atterberg limits characteristics of soils: Aspects of clay content using artificial mixtures. KSCE Journal of Civil Engineering, 2017;21(2):546-553. https://doi.org/10.1007/s12205-017-1580-z

37. Masyitah, M., N., Juliana, I., Nurin Atikah, A., Duratul Ain, T., Damanhuri, J. Correlation between california bearing ratio (CBR) with plasticity index of marine stabilizes soil with cockle shell powder: Journal of Physics:Conference Series 20191349.

\section{AUTHORS PROFILE}

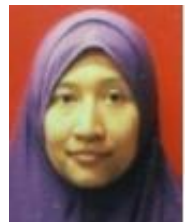

Dr. Masyitah Md Nujid is a Senior Lecturer in Civi Engineering at the University of Technology MARA UiTM Pulau Pinang. She graduated in Civil Engineering from Universiti Teknologi Malaysia (UTM) in 2005. She obtained her Master of Geotechnique from Universiti Teknologi Malaysia (UTM) in 2007. In 2017, she obtained her $\mathrm{PhD}$ in Advanced Soil Engineering from Universiti Kebangsaan Malaysia (UKM). Currently she is lecturing on Soil Mechanics, has publishes about 24 article papers in journal. Areas of interest are in the field of Soil Mechanics, Computer Modelling \& Simulation, Constitutive Soil Model and Soil Stabilization.

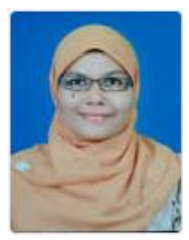

Juliana Idrus is a Senior Lecturer in Civil Engineering at the University of Technology MARA UiTM Pulau Pinang. She has nearly 25 publications in journal articles, proceeding papers, general and other articles.

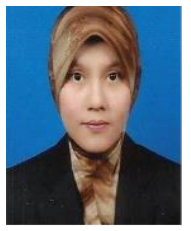

Dr. Duratul Ain Tholibon is a Senior Lecturer in Civil Engineering at the University of Technology MARA UiTM Pahang. She has nearly 30 publications in journal articles, proceeding papers, general and other articles.

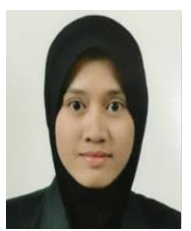

Dr. Nor Faizah Bawadi is a Lecturer in Civil Engineering at the School of Environmental Engineering, University of Malaysia Perlis. She has nearly 20 publications in journal articles, proceeding papers, general and other articles.

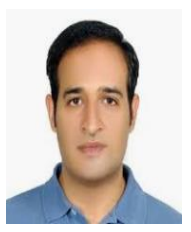

Mr.Ali Akbar Firoozi is a Researcher in Civil Engineering at the Department Civil and Structural Engineering, University of National Malaysia. He has nearly 50 publications in journal articles, proceeding papers, general and other articles. 